\title{
Author Correction: Genome-wide association study identifies susceptibility loci for acute myeloid leukemia
}

Wei-Yu Lin (1), Sarah E. Fordham, Eric Hungate, Nicola J. Sunter, Claire Elstob (1), Yaobo Xu, Catherine Park, Anne Quante, Konstantin Strauch, Christian Gieger (D), Andrew Skol, Thahira Rahman, Lara Sucheston-Campbell, Junke Wang, Theresa Hahn (1), Alyssa I. Clay-Gilmour, Gail L. Jones, Helen J. Marr, Graham H. Jackson, Tobias Menne, Mathew Collin (1), Adam Ivey, Robert K. Hills, Alan K. Burnett (1D, Nigel H. Russell, Jude Fitzgibbon (1), Richard A. Larson (1), Michelle M. Le Beau, Wendy Stock, Olaf Heidenreich, Abrar Alharbi, David J. Allsup (D), Richard S. Houlston (1), Jean Norden, Anne M. Dickinson, Elisabeth Douglas, Clare Lendrem (D), Ann K. Daly, Louise Palm, Kim Piechocki, Sally Jeffries, Martin Bornhäuser, Christoph Röllig, Heidi Altmann, Leo Ruhnke, Desiree Kunadt, Lisa Wagenführ, Heather J. Cordell (1D, Rebecca Darlay, Mette K. Andersen, Maria C. Fontana, Giovanni Martinelli, Giovanni Marconi (D), Miguel A. Sanz (D), José Cervera, Inés Gómez-Seguí, Thomas Cluzeau, Chimène Moreilhon, Sophie Raynaud, Heinz Sill (1), Maria Teresa Voso (D, Francesco Lo-Coco, Hervé Dombret, Meyling Cheok (D), Claude Preudhomme, Rosemary E. Gale, David Linch, Julia Gaal-Wesinger, Andras Masszi, Daniel Nowak (1), Wolf-Karsten Hofmann, Amanda Gilkes, Kimmo Porkka, Jelena D. Milosevic Feenstra, Robert Kralovics, David Grimwade, Manja Meggendorfer, Torsten Haferlach, Szilvia Krizsán (D, Csaba Bödör (1), Friedrich Stölzel (10), Kenan Onel (1) \& James M. Allan (1)

Correction to: Nature Communications https://doi.org/10.1038/s41467-021-26551-x, published online 29 October 2021.

In this article the author name Giovanni Marconi was incorrectly written as Giovani Marconi. The original article has been corrected.

Published online: 04 January 2022 \footnotetext{
reproduction in any medium or format, as long as you give appropriate credit to the original author(s) and the source, provide a link to the Creative Commons license, and indicate if changes were made. The images or other third party material in this article are included in the article's Creative Commons license, unless indicated otherwise in a credit line to the material. If material is not included in the article's Creative Commons license and your intended use is not permitted by statutory regulation or exceeds the permitted use, you will need to obtain permission directly from the copyright holder. To view a copy of this license, visit http://creativecommons.org/licenses/by/4.0/.
}

(c) Open Access This article is licensed under a Creative Commons Attribution 4.0 International License, which permits use, sharing, adaptation, distribution and

(c) The Author(s) 2022 